\title{
ENRICHING DIETS FOR CHILDHOOD MENTAL AND PHYSICAL DEVELOPMENT
}

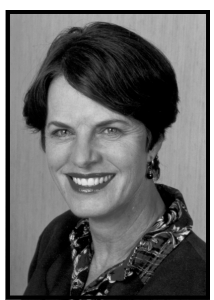

HS Kruger

MPharm, PhD (Nutrition), Diploma Hospital Dietetics

Senior lecturer, School of Physiology, Nutrition and Consumer Sciences, Potchefstroom

University for CHE

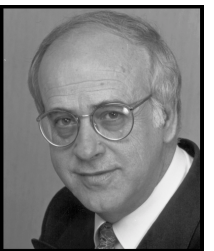

DL Labadarios

MB ChB, PhD, FACN

Head of the Department of Human Nutrition, University of Stellenbosch, Tygerberg

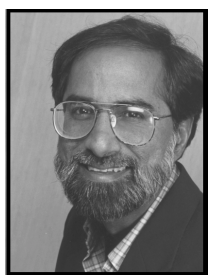

\section{MA Dhansay}

MB ChB, DCH, MMed (Paediatrics), FC Paed

Senior Specialist Scientist, Nutritional Intervention Research Unit, Medical Research Council, Tygerberg

Key words: malnutrition, children, mental development, physical development, micro-nutrients

\begin{abstract}
Malnutrition is a public health problem in South Africa, especially among rural black children. Intakes below $67 \%$ of the Recommended Dietary Allowance (RDA) are common for calcium, iron, zinc, selenium, vitamin A, C, D, E, riboflavin, niacin and vitamin B6. Key nutrients for growth and development include calcium, iron, zinc, vitamin A, folate and other B-vitamins. Calcium is essential for bone mineralisation during the adolescent growth spurt. Iron deficiency is associated with impaired growth, delayed psychomotor development and impaired immunity. Zinc is associated with normal growth, bone mineralisation and neuropsychological function. Vitamin A is essential for normal growth, eyesight and immunity. Folate is necessary for the development of new cells, especially during phases of accelerated growth. Other B-vitamins are linked to a variety of behavioural and cognitive outcomes. Factors compromising the nutritional status of children include amongst others, an inadequate nutrient intake due to poverty, inadequate nutrition education, diarrhoeal diseases, teenage dieting and allergies. To ensure optimal growth and development, strict diets should be discouraged and sound meal patterns should be encouraged, including starting the day with breakfast, and eating a variety of foods to ensure adequate intakes of nutrients and fibre. Regular physical activity promotes a healthy body weight and normal bone mineralisation.
\end{abstract}

\section{OPSOMMING}

Wanvoeding is 'n openbare gesondheidsprobleem in Suid-Afrika, veral onder plattelandse swart kinders. Mikronutriënt innames laer as $67 \%$ van die Aanbevole Dieettoelae (ADT) is algemeen vir kalsium, yster, sink, selenium, vitamien $A, C, D, E$, riboflavien, niasien en vitamien B6. Belangrike nutriënte vir groei en ontwikkeling sluit kalsium, yster, sink, vitamien A, folaat en ander B-vitamiene in. Kalsium is essensieel vir beenmineralisering tydens die adolessente snelgroeifase. Ystertekort word met belemmerde groei geassosieer, asook met vertraagde psigomotoriese ontwikkeling en verswakte immuniteit. Sink word met normale groei, 
beenmineralisering en neuropsigologiese funksie geassosieer. Vitamien A is essensieel vir normale groei, sig en immuniteit. Folaat is nodig vir die ontwikkeling van nuwe selle, veral tydens fases van versnelde groei. Ander B-vitamiene speel 'n rol in ' $n$ verskeidenheid gedrags- en kognitiewefunksies. Faktore wat die voedingstatus en gesondheid van kinders kan benadeel, sluit ' $n$ onvoldoende nutriëntinname as gevolg van onder andere, armoede, onvoldoende voedingsvoorligting, diaree, tienerdiëte en allergieë in. Om optimale groei en ontwikkeling te verseker, moet streng diëte en oorslaan van maaltye ontmoedig word en " $n$ gebalanseerde maaltydpatroon gevestig word. Ontbyt moet gereeld geëet word, tesame met ' $n$ verskeidenheid voedselsoorte, om voldoende innames van nutriënte en vesel te verseker. Gereelde fisiese aktiwiteit bevorder ' $n$ gesonde liggaamsgewig en normale beenmineralisering.

\section{INTRODUCTION}

When considering the health of children, a holistic approach includes the child's overall development, namely physical, mental, social, emotional and behavioural development. The interaction between psychosocial factors and nutrition and the effect of this interaction on mental, social and behavioural development make it difficult to assess the effects of nutrition per se on the health of children. Due to these interactions, a causal link between poor nutrition and poor development cannot easily be demonstrated. Childhood malnutrition, however, is a significant problem, known to impair both growth potential and mental development (Southon, Wright, Finglas, Bailey, Loughridge \& Walker, 1994:897-918). Recent national studies of South African children highlighted the scope of malnutrition among South African children (Labadarios \& Van Middelkoop, 1995; Labadarios, 2000:6), which may have long-term effects on their development potential.

Growth spurts are critical periods of intense growth, of which there are two, namely one during infancy and one during adolescence. During these periods children are particularly vulnerable to developing relative states of nutrient deficiency due to the high nutritional demands associated with these growth spurts (Matkovic, 1991:345S).

The purpose of this article is to review the nutritional needs of children, as well as the nutritional status of South African children and to delineate the role of specific key nutrients that may be lacking in the diets of vulnerable groups of South African children.

\section{NUTRITIONAL NEEDS OF CHILDREN}

Growth velocity is maximal during the first year of life. The infant's need for a nutrient-dense diet cannot be met beyond the age of six months by mother's milk alone. Apart from the high nutrient requirements for growth, any factor that increases nutritional needs during childhood, increases the risk of dietary inadequacy (Wright, Callum, Berks \& Jarvis, 1998:571-573).

Worldwide trends show that over the past 100 years children have become taller and often fatter too. This observation may indicate that environmental and social conditions have allowed children to grow taller (Rona \& Chin, 1995:133). Improvements in nutrition and reduction in the prevalence of disease are thought to be responsible for the increase in height, while decreased physical activity seems to be associated with the increases in weight-forheight and triceps skinfold thickness (Davies, Gregory \& White, 1995:8).

\section{THE NUTRITIONAL STATUS OF SOUTH AFRICAN CHILDREN}

\section{Anthropometric data of South African chil- dren}

The review of the nutritional status of South Afri- 
cans by the SANSS-group (SANSS, 1995) showed that malnutrition is a public health problem in this country. Within each ethnic group a wide range of percentages of children under a given anthropometric cut-point has been reported. The South African Vitamin A Consultative Group (SAVACG) undertook a comprehensive national survey of the nutritional status of pre-school children. One out of four children was stunted and one out of ten was underweight-for-age. These figures translate to about 1.5 million stunted and 660000 underweight pre-school children. The most severe prevalence of malnutrition was reported for the Eastern Cape, Northern Province and KwaZulu-Natal (Labadarios \& Van Middelkoop, 1995). The National Food Consumption Survey (NFCS) (Labadarios, 2000:6) results showed that, at a national level, one in five children aged from 1-9 years was stunted. Children on commercial farms were most adversely affected, with one out of three children being stunted. The prevalence of severe stunting, defined as a heightfor-age smaller than -3 standard deviations from the median, was also higher among children living on commercial farms. The consumption of energy and animal protein food correlated significantly with height-for-age.

Studies from the Free State and KwaZulu-Natal however suggest that a substantial number of children (10\%) are relatively overweight-for-height, with a z-score of +2 standard deviations and higher (SANSS, 1995). Six percent of children in the NFCS were overweight (Labadarios, 2000:169).

\section{Biochemical variables}

According to the SAVACG (South African Vitamin A Consultative Group) survey results, 33\% of children, 6-71 months old, on a national level had a marginal vitamin A status (serum retinol $<20 \mu \mathrm{g}$ / dL). These disadvantaged children included especially 1-4 year old children in the Northern Province and KwaZulu-Natal with poorly educated mothers. The overall prevalence of anaemia (he- moglobin $<11 \mathrm{~g} / \mathrm{dl}$ ) was $21 \%$, with the highest prevalence in the Northern Province (34\%) (SAVACG, 1995). The results of studies in KwaZulu-Natal, Northern Cape and the Western Cape are summarised in Table 1 and showed that an important proportion of white, coloured and Indian primary school children had low hemoglobin and serum ferritin concentrations and low red blood cell folate concentrations (Vorster, Oosthuizen, Jerling, Veldman \& Burger, 1997:60-62). Serum folate levels can be used as a reflection of recent folate intakes, while red blood cell folate is a better measure of long-term folate status and a better indicator of inadequacy (Bailey, 1998:296). Table 2 shows that black children also had a high prevalence of iron and folic acid deficiency (Vorster et al. 1997:56-57, 64-65).

Table 1: Biochemical nutritional status of white, coloured and Indian school children

\begin{tabular}{|c|c|c|c|c|c|}
\hline $\begin{array}{l}\text { Province, } \\
\text { Ethnic } \\
\text { group }\end{array}$ & $\begin{array}{l}\text { Age } \\
\text { Sex }\end{array}$ & $\begin{array}{l}\text { Number of } \\
\text { subjects }\end{array}$ & Variable & $\begin{array}{l}\text { Mean(standard } \\
\text { deviation) }\end{array}$ & $\begin{array}{l}\text { \% } \\
\text { Abnormal }\end{array}$ \\
\hline $\begin{array}{l}\text { Wroup } \\
\text { Western } \\
\text { Cape, } \\
\text { White }\end{array}$ & $\begin{array}{l}11 \\
\text { both }\end{array}$ & 145 & $\begin{array}{l}\text { Hemoglobin (g/dL) } \\
\text { Serum-ferritin ( } \mu \mathrm{g} / \mathrm{L} \text { ) } \\
\text { Red blood cell folate } \\
\text { (ng/mL) } \\
\text { Hemoglobin (g/dL) } \\
\text { Serum-ferritin ( } \mu \mathrm{g} / \mathrm{dL} \text { ) } \\
\text { Red blood cell folate } \\
\text { (ng/dL) }\end{array}$ & $\begin{array}{l}13.4(0.8) \\
32.3(20.4) \\
302(175) \\
13.3(1.2) \\
30.2(18.1) \\
241(129)\end{array}$ & $\begin{array}{l}4.1 \\
2.1 \\
0 \\
\\
11.3 \\
4.2 \\
16.9\end{array}$ \\
\hline $\begin{array}{l}\text { Western } \\
\text { Cape, } \\
\text { coloured }\end{array}$ & $\begin{array}{l}11 \\
\text { both }\end{array}$ & 156 & $\begin{array}{l}\text { Hemoglobin ( } \mathrm{g} / \mathrm{dL} \text { ) } \\
\text { Serum-ferritin }(\mu \mathrm{g} / \mathrm{L}) \\
\text { Red blood cell folate } \\
\text { (ng/mL) } \\
\text { Hemaglobin ( } \mathrm{g} / \mathrm{dL} \text { ) } \\
\text { Serum-ferritin }(\mu \mathrm{g} / \mathrm{dL} \text { ) }\end{array}$ & $\begin{array}{l}12.9(1.2) \\
34.4(21.4) \\
216(129) \\
12.6(1.0) \\
23.1(11.5)\end{array}$ & $\begin{array}{l}16.7 \\
1.3 \\
34.6 \\
18.4 \\
11.7\end{array}$ \\
\hline $\begin{array}{l}\text { KwaZulu- } \\
\text { Natal, } \\
\text { Indian }\end{array}$ & $\begin{array}{l}10+ \\
\text { girls }\end{array}$ & $\begin{array}{l}161 \\
164\end{array}$ & $\begin{array}{l}\text { Hemoglobin }(g / d L) \\
\text { Serum-ferritin }(\mu g / L) \\
\text { Hemoglobin }(g / d L) \\
\text { Serum-ferritin }(\mu g / L)\end{array}$ & $\begin{array}{l}12.77(1.38) \\
12(4) \\
12.47(1.39) \\
12(4)\end{array}$ & $\begin{array}{l}\text { Not } \\
\text { described }\end{array}$ \\
\hline
\end{tabular}

Table 2: Biochemical nutritional status of black school children

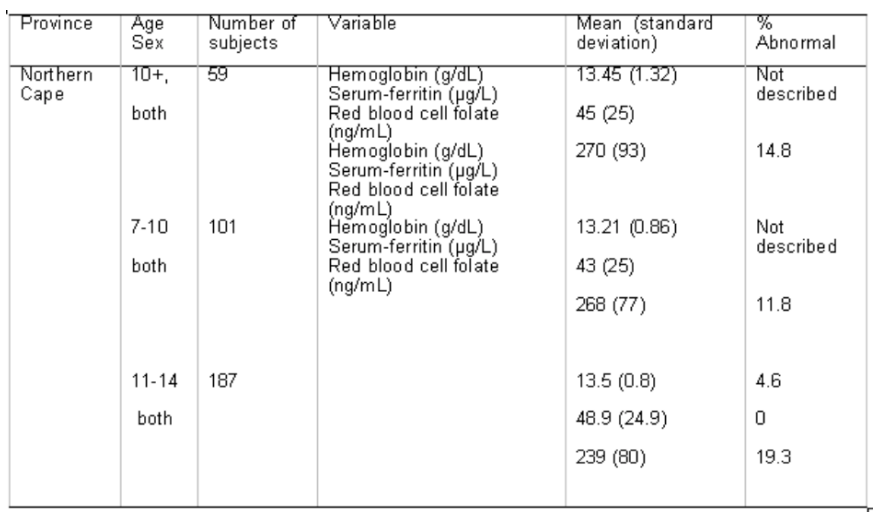

\section{Nutrient intakes}

Almost one out of two children younger than nine years in the NFCS had energy intakes less than half of their daily energy needs (Labadarios, 2000:10). According to the SANSS-data, however, the energy 
and protein intakes of children in all population groups seemed to be adequate, except in 2-6 year old rural black children. Very few of the groups studied had mean fibre intakes which met the dietary recommendation of age +5 gram of fibre per day (SANNS, 1995).

According to the SANSS data, summarised in Table 3 , children from all age and population groups had mean vitamin B6 intakes lower than the RDA. Generally, coloured and rural black children had intakes lower than the LRNI (lower reference nutrient intake) and the EAR (estimated average requirement). Mean iron and zinc intakes below the RDA were also found in most of the groups of children studied, especially in girls 11-15.9 years old, of all popu-

Table 3: Micronutrient intakes of South African children

\begin{tabular}{|c|c|c|c|c|c|c|c|c|c|c|}
\hline Age, sex & $\begin{array}{l}\text { White mean } \\
(\mathrm{SD})\end{array}$ & $\mathbb{N}$ & $\begin{array}{l}\text { Urban black } \\
\text { mean (SD) }\end{array}$ & $\mathbb{N}$ & $\begin{array}{l}\text { Coloured } \\
\text { mean (SD) }\end{array}$ & $\mathbb{N}$ & $\begin{array}{l}\text { Indian mean } \\
(\mathrm{SD})\end{array}$ & $\begin{array}{l}\text { Rural black } \\
\text { mean (SD) }\end{array}$ & $\mathbb{N}$ & $\mathrm{RDA}^{*}$ \\
\hline & Iron (mg) & & & & & & & & & \\
\hline 6-11, both & $9.3(4.5)$ & 12 & $8(4.5)$ & 13 & $12.9(6.3)$ & 24 & $\begin{array}{l}\text { Not } \\
\text { measured }\end{array}$ & $13(7)$ & 47 & 10 \\
\hline $\begin{array}{l}11-16, \\
\text { boys }\end{array}$ & $13.5(6)$ & $\begin{array}{l}16 \\
3\end{array}$ & $11(4)$ & 47 & $10(5.1)$ & $\begin{array}{l}17 \\
3\end{array}$ & $\begin{array}{l}\text { Not } \\
\text { measured }\end{array}$ & $12.5(15.9)$ & 140 & 12 \\
\hline \multirow[t]{2}{*}{$\begin{array}{l}11-16, \\
\text { girls }\end{array}$} & $9.5(3.6)$ & $\begin{array}{l}16 \\
4\end{array}$ & $10(5)$ & 47 & $8(3.5)$ & $\begin{array}{l}16 \\
7 \\
\end{array}$ & $\begin{array}{l}\text { Not } \\
\text { measured }\end{array}$ & $10.6(4.4)$ & 160 & 15 \\
\hline & Zinc (mg) & & & & & & & & & \\
\hline 6-11, both & $\begin{array}{l}\text { Not } \\
\text { measured }\end{array}$ & & $6.1(3.6)$ & 13 & $11.1(5.4)$ & 24 & $\begin{array}{l}\text { Not } \\
\text { measured }\end{array}$ & $9(4)$ & 47 & 10 \\
\hline $\begin{array}{l}11-16, \\
\text { bous }\end{array}$ & $12(6)$ & $\begin{array}{l}16 \\
3\end{array}$ & $9(5)$ & 47 & $9(6)$ & $\begin{array}{l}17 \\
3\end{array}$ & $\begin{array}{l}\text { Not } \\
\text { measured }\end{array}$ & $8.4(4.9)$ & 140 & 15 \\
\hline \multirow[t]{2}{*}{$\begin{array}{l}11-16, \\
\text { girls }\end{array}$} & $9(4.5)$ & $\begin{array}{l}16 \\
4\end{array}$ & $8(5)$ & 47 & $7.5(4.5)$ & $\begin{array}{l}16 \\
7\end{array}$ & $\begin{array}{l}\text { Not } \\
\text { measured }\end{array}$ & $7.6(4)$ & 160 & 12 \\
\hline & $\begin{array}{l}\text { Vitamin } B_{6} \\
\text { (mg) }\end{array}$ & & & & & & & & & \\
\hline E-11, both & $\begin{array}{l}\text { Not } \\
\text { measured }\end{array}$ & & $0.7(0.3)$ & 13 & $1.2(0.6)$ & 24 & $\begin{array}{l}\text { Not } \\
\text { measured }\end{array}$ & $0.5(0.4)$ & 47 & 1.4 \\
\hline $\begin{array}{l}11-16, \\
\text { boys }\end{array}$ & $1.5(0.8)$ & $\begin{array}{l}16 \\
3\end{array}$ & $0.9(0.5)$ & 47 & $1.1(0.7)$ & $\begin{array}{l}17 \\
3\end{array}$ & $\begin{array}{l}\text { Not } \\
\text { measured }\end{array}$ & $0.8(0.9)$ & 140 & 2.0 \\
\hline \multirow[t]{2}{*}{$\begin{array}{l}11-16, \\
\text { girls }\end{array}$} & $1.1(0.6)$ & $\begin{array}{l}16 \\
4\end{array}$ & $1.1(0.7)$ & 47 & $1(0.6)$ & $\begin{array}{l}16 \\
7\end{array}$ & $\begin{array}{l}\text { Not } \\
\text { measured }\end{array}$ & $0.7(0.6)$ & 160 & 1.4 \\
\hline & Folate $(\mu \mathrm{g})$ & & & & & & & & & \\
\hline 6-11, both & $\begin{array}{l}\text { Not } \\
\text { measured }\end{array}$ & & $162(92)$ & 13 & $230(139)$ & 24 & $\begin{array}{l}\text { Not } \\
\text { measured }\end{array}$ & $113(70)$ & 47 & 100 \\
\hline $\begin{array}{l}11-16, \\
\text { boys }\end{array}$ & $215(122)$ & $\begin{array}{l}16 \\
3\end{array}$ & $164(91)$ & 47 & $145(92)$ & $\begin{array}{l}17 \\
3\end{array}$ & $\begin{array}{l}\text { Not } \\
\text { measured }\end{array}$ & $113(73)$ & 140 & 150 \\
\hline $\begin{array}{l}11-16 \\
\text { girls }\end{array}$ & $162(85)$ & $\begin{array}{l}16 \\
4\end{array}$ & $157(129)$ & 47 & $121(62)$ & $\begin{array}{l}16 \\
7\end{array}$ & $\begin{array}{l}\text { Not } \\
\text { measured }\end{array}$ & $101(69)$ & 160 & 150 \\
\hline
\end{tabular}

lation groups. Zinc has been identified as one of the micronutrients in the diet of South African children that needs immediate attention. The mean intakes of the study samples are probably not the best indicator of vitamin A status, since many children had sub-optimal intakes. The national SAVACG study (1995) showed that more than $30 \%$ of young children had a marginal vitamin A status. Western Cape (Steyn, Wicht, Rossouw, Kotze \& Van Eck, 1989:15) and Northern Cape (Steyn, Pettifor, van der Westhuizen \& Van Niekerk, 1990:52) black and coloured teenagers had mean folate intakes below $67 \%$ of the RDA and also low red blood cell folate levels. According to the NFCS results the majority of children had deficient intakes of multiple micronutrients. Generally, the intakes of calcium, iron, zinc, selenium, vitamin A, C, D and E, riboflavin, niacin and vitamin $\mathrm{B} 6$ were less than $67 \%$ of the RDA (Labadarios, 2000:10).

\section{KEY NUTRIENTS FOR GROWTH AND DEVELOPMENT}

Calcium needs relative to body size are the greatest during the first year of life, when skeletal mass doubles (Matkovic, 1991:245S). During the preschool and early school years children still need 2-4 times more calcium per kilogram of body weight than adults. The velocity of bone growth doubles during adolescence up to 17 years of age, when $90 \%$ of the peak bone mass has been achieved (Teegarden, Praulx, Martin, Zhao, McCabe, Lyte, Peacock, Stemenda, Johnstone \& Weaver, 1995:711). Every opportunity should therefore be used to increase bone mass, by ensuring an optimal calcium intake, since an optimal calcium intake is associated with a reduction in the risk of developing osteoporosis later in life (Heany, 1993:287). About half to $75 \%$ of the peak bone mass is genetically determined, while the remainder is influenced by hormonal and lifestyle factors, including calcium intake and physical activity. Dieting teenage girls are particularly vulnerable to deficient calcium intakes. A number of studies have shown that increased calcium intake enhances the rate of increase in bone mineral density in children and adolescents (Johnstone, Miller, Stemenda, Reister, Hui, Christian \& Peacock, 1992:82; Bonjour, Carrie, Ferrari, Clavien, Slosman, Theintz \& Rizzoli, 1997:1287). Eight-year old girls with a low habitual calcium intake were studied by Bonjour et al. (1997:1287). A calcium enriched diet increased bone density and height of the supplemented group, compared to controls. It has been 
speculated, however, that the height increase could be explained by increased levels of insulin-like growth factor (IGF-I) in girls who increased their milk intake (Cadogan, Eastell, Jones \& Barker, 1997:1255).

Children with a higher consumption of milk have higher calcium intakes. Strategies to increase calcium intake in dieting adolescent girls should include the promotion of a fortified breakfast of cereal and low-fat milk or yogurt. Concern has been expressed that high calcium intakes may interfere with iron absorption. However, a recent calcium supplementation trial provided reassurance that an average calcium intake of $1500 \mathrm{mg}$ per day was still associated with favourable serum ferritin and hemoglobin levels, indicating no detrimental effect of a high calcium intake on iron status (FairweatherTait, 1995:465).

Iron deficiency is associated with loss of appetite and proneness to infection, resulting in higher morbidity and growth retardation in children. In infancy and adolescence the iron requirements are high to meet the demands of rapid growth. Adolescent girls have the added burden of replacing iron lost with menstruation. Increased demands, often coupled with self-imposed dieting, make teenage girls vulnerable to iron deficiency (Crawley \& ShergillBonner, 1995:25). Studies in the United Kingdom showed that meat products were the most important food sources of iron followed by fortified breakfast cereals (McNulty, Eaton-Evans, Cran, Woulahan, Boreham, Savage, Fletcher \& Strain, 1996:477).

Poor weight gain in infants and young children may be a consequence of iron deficiency. Although a tendency for anaemic children to be shorter and lighter than the reference standards has been reported, there are, however, several studies, which indicate that anaemic children, who were otherwise well nourished, were comparable in weight and height to the growth standards (Payne \& Belton,
1992:299). A consistent body of evidence suggests that when anaemic children receive iron supplements, their growth improves (Lawless, Latham, Stephenson, Kinoti \& Pertet, 1994:645). The mechanism for iron-impaired growth is uncertain, but reduced illness and improved appetite and food intake have been suggested. In a study of Indonesian school children, anaemic children were initially lighter and shorter than their non-anaemic counterparts. The authors speculated that this growth retardation could be due to higher morbidity in anaemic children, because impaired cellular immunity seems to accompany iron-deficiency anaemia (Dallmann, 1987:329). In Indonesian preschool children a two month period of iron supplementation had a positive effect on the linear growth of stunted children. When iron-supplemented children were compared with a control (unsupplemented) group, the change in height of the supplemented group was 1.8 times greater than in the supplemented group. The food intake of the supplemented group was not increased, but a decrease in morbidity was evident. These data suggest that iron deficiency is a growth limiting factor in young children and underlines the importance of iron in the diet of children (Angeles, Schultink, Matulessi, Gross \& Sastroamidjojo, 1993:339). Vitamin $\mathrm{C}$ is known to promote the absorption of non-haem iron from the gastrointestinal tract and can thus, indirectly, contribute to an improved iron status.

In a recent study (Fairweather-Tait, 1995:467) trends for a positive association between bone mineral density and serum ferritin were found. The authors suggested that iron acts as a cofactor for enzymes involved in the synthesis of bone matrix collagen. Iron deficiency may also impact on bone strength indirectly, because physical activity (a promoter of bone strength) is compromised in anaemic children (Ilich-Ernst, McKenna, Badenhop, Clairmont, Andon, Nahhas, Goel \& Matkovic, 1998:880). Physical activity is an important prerequisite for maximising bone mass during adoles- 
cence.

Iron deficiency has also been shown to be related to a delay in psychomotor development, more specifically to poor cognitive function and educational achievement (Lozoff, Klein, Nelson, McClish, Manuel \& Chacon, 1998:24). Costa Rican infants with iron deficiency maintained closer contact with caregivers, were less attentive and playful and were tired more easily than non-anaemic controls (Lozoff et al. 1998:24). In 9-11 year old Indonesian schoolchildren, non-anaemic children performed better in school tests than their anaemic counterparts (Idjradinata \& Pollitt, 1993:571). The mechanism for the developmental effects of iron deficiency is not clear, but may be associated with nerve myelination or levels of brain neurotransmitters (Pollitt $\&$ Mathews, 1998:804S). Iron supplementation of school children with poor iron status resulted in significant improvements in cognitive tests (Pollitt \& Mathews, 1998:804S). These results, however, could not be confirmed by a study in the UK, where no relationship was found between iron status and intelligence tests. Nevertheless it should be borne in mind that intelligence depends more on genetic and other environmental factors than on nutritional status. Several other studies have also shown that non-anaemic children did not benefit from iron supplementation (Nelson, 1980:35; Southon et al. 1994:897). Children with a satisfactory nutritional status will not perform better in cognitive or academic achievement tests after iron supplementation.

Zinc is required for a wide range of growth related metabolic processes, including DNA and protein synthesis (Prasad, 1996:113). Growth retardation is characteristic of zinc deficiency in children. Hambidge, Chaves, Brown and Walravens (1979:2532) reported short stature in otherwise well-nourished middle-class American children, with signs of zinc deficiency, namely low hair zinc concentrations. Two to 6 year old children with a height-for-age below the 10th percentile, who had their diets supplemented with zinc for 12 months showed an improved gain in height and increased food intake when compared with non-supplemented controls. The mechanism whereby zinc affects growth may involve IGF-I, which stimulates the synthesis of DNA and RNA. In stunted children who were zinc deficient, zinc supplementation increased serum IGF-I levels (Nakamura, Nishiyama, Futagoishi-Suginohara, Matsuda \& Higashi, 1993:65). It should however be borne in mind that most studies of the association between zinc status and growth have been conducted in developing countries and may not be relevant to well-nourished children populations. The incidence of growth-limiting zinc deficiency in South Africa is unknown, but the generally low zinc intakes of children found in the NFCS (Labadarios, 2000:240, 341) increase the probability of sub-optimal zinc status, especially in rural areas, where a relatively high rate of stunting was found (Labadarios, 2000:7).

Animal (Golub, Keen, Gershwin, Styne, Takeuchi, Ontell, Walker \& Hendrickx, 1996:274) and human studies (King, 1996:375) have shown that zinc intake during adolescence may also influence bone mineralisation and achievement of peak bone mass. A moderate deprivation of dietary zinc in rhesus monkeys during their pubertal growth spurt retarded skeletal mineralisation (Golub et al. 1996:274). A study of 6-9 year old Chinese children with marginal zinc status reported that those children who received supplementary zinc for 10 weeks performed better in a battery of neuropsychological tests than controls (Penland, Sandstead, Alcock, Dayal, Chen, Li, Zhao \& Yand, 1997:268). The tests included fine and gross motor skills, hand-eye coordination, visual perception, conception formation, abstract reasoning and attention span. However, studies in Guatemalan school children (Cavan, Gibson, Grazioso, Isalgue, Ruz \& Solomons, 1993:344) and 5-7 year old boys with a growthlimiting mild zinc deficiency syndrome in Canada (Gibson, Vanderkooy, MacDonald, Golman, Ryan \& Berry, 1989:1266) could not confirm the results 
of the Chinese study, although these studies used fewer measures of cognitive function than those included in the study of Chinese children.

Zinc and iron may interfere with one another's absorption by competing for the same absorptive pathways. Fairweather-Tait (1995:465) concludes that such interactions are only likely to be of nutritional importance at levels of intake achieved by the use of supplements and not at the level derived from foods, and recommended that supplements be taken between meals. The author also stated that the fortification of food with iron is unlikely to decrease zinc absorption significantly.

Vitamin A is essential for normal growth, eyesight, bone development, the immunity, as well as for the maintenance of epithelial tissue. Vitamin A supports normal growth, probably by regulating nocturnal growth hormone secretion (Evain-Brion, Porquet, Therond, Flellerstadt-Paulsen, Greneche, Francois \& Czernichow, 1994:87). The association between vitamin A status and growth may also be explained by the role of vitamin $\mathrm{A}$ in reducing infection and allowing optimal growth. Vitamin A deficiency is also associated with iron deficiency anaemia, which is correctable by enriching the diet with both iron and vitamin A, since vitamin A helps to utilise endogenous iron stores (Bloem, Wedel, Egger, Andries, Speek, Schrijver, Saowakontha \& Schreuers, 1989:332). Vitamin A deficiency has been shown to increases host susceptibility to infections and diarrhoea through its role in maintaining the integrity of mucous membranes (Combs, 2000:72).

Folate is essential for growth and development of new cells, including the haemopoietic cells in the bone marrow. Folate deficiency results in a slowing of cell division and eventually megaloblastic anaemia. An adequate folate intake is essential for growth, especially during the periods of accelerated growth (Bailey, 1998:294; Matoth, Zehavi, Topper \& Klein, 1979:699). The relationship be- tween folate deficiency of the mother and neural tube defects of the newborn underlines the importance of folate in the diet of young women. Studies of teenagers in London (McNulty et al. 1996:477) and Northern Ireland (Doyle, Jenkins, Crawford, \& Puvandendran, 1994:378) suggest sub-optimal folate intakes among teenagers. Since folate is involved in DNA and RNA synthesis, there is an increased demand for folate during the adolescent growth spurt. Sub-optimal folate status in female teenagers may increase the risk of neural tube defects in babies born of these women in later life (Bailey, 1998:294).

Vitamin B status, particularly vitamin B6 has been linked to a variety of behavioural and cognitive outcomes. However, available evidence from observational studies (Wachs, 1995:2245S-2254S) cannot be regarded as proof of cause and effect. It is, however, generally accepted that vitamin B6 plays an important role in the neurotransmitter systems involved in learning and memory (Guilarte, 1993:193).

\section{FACTORS COMPROMISING THE NU- TRITIONAL STATUS AND HEALTH OF CHILDREN}

\section{Poverty and hunger}

At a national level, one out of two households (52\%) surveyed in the NFCS experienced hunger, one out of four $(23 \%)$ were at risk of hunger and only $25 \%$ appeared food secure. The highest percentage of hunger was reported in the Eastern Cape (83\%), North Cape (63\%), North West (61\%), Northern Province (54\%) and Mpumalanga (53\%). Significant differences in the stunting rate between food secure and insecure households were found. The intakes of energy, as well as a number of nutrients were the lowest in the households that experienced hunger (Labadarios, 2000) 


\section{Teenage dieting}

Studies from Europe and the United States have shown that a high percentage of teenage girls are attempting to lose weight. Girls' perceptions of their own body size and weight are often different from reality. Low intakes of iron, calcium, zinc and Bvitamins were reported for dieting teenagers, which may result in iron-deficiency anaemia and an increased risk of future osteoporosis. Peer pressure, poor dietary habits and ignorance are among the factors that make this group a high risk group for dietary inadequacies (Crawley \& Shergill-Bonner, 1995:25).

\section{Overweight and obesity}

Worldwide trends indicate an increase in the prevalence of overweight and obesity in children. According to the SANSS data about $10 \%$ of the children included in studies were relatively overweightfor-height (SANSS, 1995). In the NFCS the prevalence of overweight was the highest among children living in urban areas and whose mothers were better educated. The national prevalence of overweight was $6 \%$ and remained constant in all age groups (Labadarios, 2000:169). Indications are that physical inactivity shows a stronger relationship with body fat percentage in children than energy intake (Davies, Gregory \& White, 1995:6). Childhood obesity is associated with psychosocial problems, which have a negative effect on self-esteem and general well-being (Must \& Strauss, 1999:S8).

\section{The squash-drinking syndrome}

Failure to thrive and frequent episodes of diarrhoea in young children have been associated with a regular consumption of cold drinks between meals. Large volumes of juice-based drinks reduce the appetite for more nutrient-dense foods at mealtimes and may cause growth failure in young children (Hourihane \& Rolles, 1995:142).

\section{Constipation}

Constipation is regarded as a common childhood condition, especially between the ages of one and five years. As in adults, insufficient fibre in the diet is an important cause of constipation, although behavioural problems and colonic disease may also be involved (Roma, Adamidis, Nikolara, Constantopoulos \& Messaritakis, 1999:169). Increasing the fibre intake gradually can be used successfully to treat childhood constipation (Hillemeier, 1995:997). The mechanism whereby constipation is related to unsatisfactory nutrient intakes and growth appears to be a vicious cycle, whereby a loaded rectum causes the child to feel anorexic, causing a decreased food intake, again followed by a decreased fibre content of the colon (Roma et al. 1999:172). It may, however, also be true that children, who do not eat well, are more likely to become constipated, rather than that constipated children do not eat well.

\section{Food intolerance and allergies}

The prevalence of adverse reactions to food in infants and children worldwide is estimated to be approximately $2-8 \%$. Associated signs and symptoms of food intolerance include vomiting, diarrhoea, gastrointestinal blood loss, skin rash and wheezing (Wilson, 2000:915). Food allergies may lead to a lack of variety in the diet, because important food groups, such as milk or wheat products may have to be avoided and may thus contribute to an inadequate dietary intake of key nutrients (Tiainen, Nuutinien \& Kalavainen, 1995:10-12). Adverse reactions to milk include lactose intolerance and cow's milk protein allergy. Avoidance of milk removes an important source of energy, protein and calcium from the diet, and as such alternatives should be sought with expert help, since inadequate energy and protein intakes have been associated with linear growth retardation in these children (Lloyd-Still, 1979:11). 


\section{CONCLUSION AND RECOMMENDA- TIONS}

From the available data it is clear that many South African children have inadequate intakes of calcium, iron, zinc, vitamin A, folate and vitamin B6 (Steyn, Wicht, Rossouw, Kotze \& Van Eck, 1989:15; Steyn, Pettifor, Van der Westhuizen \& Van Niekerk, 1990:52; Labadarios \& Van Middelkoop, 1995; Labadarios, 2000:10). Childhood micronutrient malnutrition has been shown to be associated with stunted growth (Hambidge, Chaves, Brown \& Walravens, 1979:2532) impaired immunity (Dallmann, 1987:329; Crawley \& ShergillBonner, 1995:25; Combs, 2000:72), poor cognitive function (Lozoff et al. 1998:24) and anaemia (Dallmann, 1987:329; Bailey, 1998:294). Poverty appears to be an important determinant of inadequate nutrient intakes in South Africa, especially in the Eastern Cape, North Cape and North West Province (Labadarios, 2000:10).

To promote an optimal intake of the key nutrients for normal physical and mental development of children, healthy eating habits should be advised. Children, under the influence of peer groups, often have strange eating habits, excluding important food groups, such as fruit and vegetables. Although mothers may have adequate knowledge of a balanced diet, the food preferences of the child may make it difficult to include a variety of foods daily. Some basic recommendations may help mothers to balance the diets of their children within the limitations of time, budgetary constraints and the child's food preferences.

The omission of breakfast will impact negatively on the nutritional status of children, since the nutrients lost by skipping breakfast cannot be, and are usually not, easily replaced later in the day. Studies in the United States showed that breakfast skippers consumed less than $60 \%$ of the recommended intakes of calcium and iron, while individuals who consumed ready-to-eat cereals and milk had higher average daily intakes of these "problem nutrients" and lower intakes of fat (Nicklas, Bao, Webber \& Berenson, 1993:886). In households where readyto-eat cereals cannot be afforded, fortified maize meal should be bought instead of unfortified maize. Regular cereal and fruit intakes increase dietary fibre intakes of children and will help to decrease the problem of constipation. Breakfast consumption is also reported to have beneficial effects for some cognitive functions and physical performance (Pollitt \& Mathews, 1998:804S). Teenage dieters may need extra encouragement to eat breakfast, since they may believe that skipping breakfast will help them to lose weight (Crawley \& ShergillBonner, 1995:25). The results of available studies show that the opposite may be true, since subjects who ate breakfast found it easier to lose weight than those who skipped breakfast, but ate more food at dinner (Rona \& Chin, 1995:133).

The emphasis of any nutritional advice given should be on a daily intake of whole-wheat products, fruit and vegetables, milk and moderate portions of meat, fats and sugar. Brown bread is cheaper and has a higher iron, B vitamin and fibre content than white bread. Fortified cereals, for example maize meal, bread and ready-to-eat breakfast cereals make it easier to obtain a variety of nutrients in one meal (McNulty et al. 1996:474), especially for children who dislike vegetables and fruit. In children who are allergic to milk, special attempts should be made to include sufficient calcium in the diet, by supplementing the diet. Regular physical activity promotes a healthy body weight (Davies, Gregory \& White, 1995:6), as well as normal bone mineralisation (Heany, 1993:287). Although many factors affect the physical and mental development of children, an optimal nutritional status helps children to optimise their genetic potential.

\section{REFERENCES}

ANGELES, IJ; SCHULTINK, WJ; MATULESSI, P; GROSS, R \& SASTROAMIDJOJO, S 1993: Decreased 
rate of stunting among anaemic Indonesian pre-school children through iron supplementation. American Journal of Clinical Nutrition, 58:339-342.

BAILEY, LB 1998: Dietary reference intakes for folate: the debut of dietary folate equivalents. Nutrition Reviews, 56:294-299.

BLOEM, MW; WEDEL, M; EGGER, RJ; ANDRIES, M SPEEK, AJ SCHRIJVER, J SAOWAKONTHA, S \& SCHREUERS, WHP 1989: Iron metabolism and vitamin A deficiency in children in North-East Thailand. American Journal of Clinical Nutrition, 50:332-338. BONJOUR, JP; CARRIE, AL; FERRARI, S; CLAVIEN, H; SLOSMAN, D; THEINTZ, G \& RIZZOLI, R 1997: Calcium enriched foods and bone mass growth in prepubertal girls: a randomised, doubleblind placebo-controlled trial. Journal of Clinical Investigation, 99:12871294.

CADOGAN, J; EASTELL, R; JONES, N \& BARKER, ME 1997: Milk intake and bone mineral acquisition in adolescent girls: randomised, controlled intervention trial. British Medical Journal, 315:1255-1260.

CAVAN, KR; GIBSON, RS; GRAZIOSO, CF; ISALGUE, AM; RUZ, M \& SOLOMONS, NW 1993: Growth and body composition of peri-urban Guatemalan children in relation to zinc status: a longitudinal zinc intervention trial. American Journal of Clinical Nutrition, 57:344-352.

COMBS, GF 2000: Vitamins. (In: Mahan LK \& EscottStump S eds. 2000: Krause's Food, nutrition and diet therapy. Philadelphia: WB Saunders Company. pp. 67109.)

CRAWLEY, HF \& SHERGILL-BONNER, R 1995: The nutrient and food intakes of 16-17 year old female dieters. Journal of Human Nutrition and Dietetics, 8:2534.

Dallmann, PR 1987: Iron deficiency and the immune response. American Journal of Clinical Nutrition, 46:329-334.

DAVIES, PSW; GREGORY J \& WHITE A 1995: Physical activity and body fatness in pre-school children. International Journal of Obesity, 19:6-10.

DOYLE, W; JENKINS, S; CRAWFORD, MA \& PUVANDENDRAN, K 1994: Nutritional status of schoolchildren in an inner-city area. Archives of Dis- eases of Childhood, 7:376-381.

EVAIN-BRION, D; PORQUET, D; THEROND, P; FLELLERSTADT-PAULSEN, A; GRENECHE, MO; FRANCOIS, L \& CZERNICHOW, P 1994: Vitamin A deficiency and nocturnal growth hormone secretion in short children. Lancet, 343:87-88.

FAIRWEATHER-TAIT, SJ 1995: Iron-zinc and calciumzinc interactions in relation to zinc absorption. Proceedings of the Nutrition Society, 54:465-473.

GIBSON, RS; VANDERKOOY, PD; MACDONALD, AC; GOLMAN, A; RYAN, BA \& BERRY, MA 1989: Growth-limiting, mild zinc deficiency syndrome in some Southern Ontario boys with low height percentiles. American Journal of Clinical Nutrition, 49:12661273.

GOLUB, MS; KEEN, CL; GERSHWIN, ME; STYNE, DM; TAKEUCHI, PT; ONTELL, F; WALKER, RM \& HENDRICKX, AG 1996: Adolescent growth and maturation in zinc-deprived rhesus monkeys. American Journal of Clinical Nutrition, 64:274-282.

GUILARTE, TR 1993: Vitamin B6 and cognitive development: recent research findings from human and animal studies. Nutrition Reviews, 51:193-198.

HAMBIDGE, KM; CHAVES, MN; BROWN, RM \& WALRAVENS, PA 1979: Zinc nutritional status of young middle-income children and effects of consuming zincfortified breakfast cereals. American Journal of Clinical Nutrition, 32(12):2532-2539.

HEANY, RP 1993: Nutritional factors in osteoporosis. Annual Reviews of Nutrition, pp. 287-316.

HILLEMEIER, C 1995: An overview of the effects of dietary fiber on gastrointestinal transit. Pediatrics, 96:997-999.

HOURIHANE, JO'B \& ROLLES, CJ 1995: Morbidity from excessive intake of high-energy fluids: the squash drinking syndrome. Archives of Diseases of Childhood, 72:141-143.

IDJRADINATA, P \& POLLITT, E 1993: Reversal of developmental delays in iron-deficient anaemic infants treated with iron. Lancet, 341:571-572.

ILICH-ERNST, JZ; MCKENNA, AA; BADENHOP, NE; CLAIRMONT, AC; ANDON, MB; NAHHAS, RW; GOEL, P \& MATKOVIC, V 1998: Iron status, menarche and calcium supplementation in adolescent girls. Ameri- 
can Journal of Clinical Nutrition, 68:880-887.

JOHNSTONE, CC; MILLER, JZ; STEMENDA, CW; REISTER, TK; HUI, S; CHRISTIAN, JC \& PEACOCK, M 1992: Calcium supplementation and increases in bone mineral density in children. New England Journal of Medicine, 327:82-87.

KING, JC 1996: Does poor zinc nutriture retard skeletal growth and mineralisation in adolescents? American Journal of Clinical Nutrition, 64:375-376.

LABADARIOS, D \& VAN MIDDELKOOP, AM eds. 1995: Children aged 6 to 71 months in South Africa, 1994. Their anthropometric, vitamin A, iron and immunisation coverage status. Isando: SAVACG.

LABADARIOS, D ed. 2000: The National Food Consumption Survey (NFCS): Children aged 1-9 years, South Africa, 1999. Stellenbosch: NFCS.

LAWLESS, JW; LATHAM, MC; STEPHENSON, LS; KINOTI SN \& PERTET, AM 1994: Iron supplementation improves appetite and growth in anemic Kenyan primary school children. Journal of Nutrition, 124:645654.

LLOYD-STILL, JD 1979: Chronic diarrhoea of childhood and the misuse of elimination diets. Journal of Pediatrics, 95:10-13.

LOZOFF, B; KLEIN, NK; NELSON, EC; MCCLISH, DK; MANUEL, M \& CHACON, ME 1998: Behaviour of infants with iron-deficiency anemia. Child Development, 69:24-36.

MATKOVIC, V 1991: Calcium metabolism and calcium requirements during skeletal modeling and consolidation of bone mass. American Journal of Clinical Nutrition, 54(Suppl):245S-260S.

MATOTH, Y; ZEHAVI, I; TOPPER, E \& KLEIN, T 1979: Folate nutrition and growth in infancy. Archives of Diseases of Childhood, 54(9):699-702.

MCNULTY, H; EATON-EVANS, J; CRAN, G; WOULAHAN, G; BOREHAM, C; SAVAGE, JM; FLETCHER, R \& STRAIN, JJ 1996: Nutrient intakes and impact of fortified breakfast cereals in schoolchildren. Archives of Diseases of Childhood, 75:474-481. MUST, A \& STRAUSS, RS 1999: Risks and consequences of childhood and adolescent obesity. International Journal of Obesity, 23:S2-S11.

NAKAMURA, T; NISHIYAMA, S; FUTAGOISHI-
SUGINOHARA, Y; MATSUDA, I \& HIGASHI, A 1993: Mild to moderate zinc deficiency in short children: effect of zinc supplementation on linear growth velocity. Journal of Pediatrics, 123:65-69.

NELSON, M 1980: Assessing dietary intake and its relation to growth in British children. Proceedings of the Nutrition Society, 39:35-42.

NICKLAS, TA; BAO, W; WEBBER, LS \& BERENSON, GS 1993: Breakfast consumption affects adequacy of total daily intake in children. Journal of the American Dietetic Association, 93:886-891.

PAYNE, JA \& BELTON, NR 1992: Nutrient intake and growth in preschool children II: intake of minerals and vitamins. Journal of Human Nutrition and Dietetics, 5:299-304.

PENLAND, JG; SANDSTEAD, HH; ALCOCK, NW; DAYAL, HH; CHEN, XC; LI, JS; ZHAO, F \& YAND, JJ 1997: A preliminary report: effects of zinc and micronutrient repletion on growth and neuropsychological function of urban Chinese children. Journal of the American College of Nutrition, 16(3):268-272.

POLLITT, E \& MATHEWS, R 1998: Breakfast and cognition: an integrative summary. American Journal of Clinical Nutrition, 67(4)(Suppl):804S-813S.

Prasad, AS 1996: Zinc deficiency in women, infants and children. Journal of the American College of Nutrition, 15:113-120.

ROMA, E; ADAMIDIS, D; NIKOLARA, R; CONSTANTOPOULOS, A \& MESSARITAKIS, J 1999: Diet and chronic constipation in children: the role of fiber. Journal of Pediatric Gastroenterological Nutrition, 28(2):169-174.

RONA, RJ \& CHIN, S 1995: Genetic and environmental influences on growth. Journal of Medical Screening, 2(3):133-139.

SANSS 1995: Nutrient intakes of South Africans: an analysis of the literature. Unpublished report to Roche on behalf of the SANSS consultative group.

SOUTHON, SA; WRIGHT, AJ; FINGLAS, PM; BAILEY, AL; LOUGHRIDGE, JM \& WALKER, AD 1994: Dietary intake and micronutrient status of adolescents: effects of vitamin and trace element supplementation on indices of status and performance in tests of verbal and non-verbal intelligence. British Journal of 
Nutrition, 71(6):897-918.

STEYN, NP; WICHT, CL; ROSSOUW, JE; KOTZE, TJVW \& VAN ECK, M 1989: Nutritional status of 11year-old children in the Western Cape I. Dietary intake. South African Journal of Food Science and Nutrition, 1(1):15-20.

STEYN, NP; PETTIFOR, JM; VAN DER WESTHUIZEN, J \& VAN NIEKERK, L 1990: Nutritional status of school children in the Richtersveld. South African Journal of Food Science and Nutrition, 2(3):52-56.

TEEGARDEN, D; PRAULX, WR; MARTIN, BR; ZHAO, J; MCCABE, GP; LYTE, RM; PEACOCK, M; STEMENDA, C; JOHNSTONE CC \& WEAVER, CM 1995: Peak bone mass in young women. Journal of Bone and Mineral Research, 10:711-715.

TIAINEN, JM; NUUTINIEN, OM \& KALAVAINEN, MP 1995: Diet and nutritional status in children with cow's milk allergy. European Journal of Clinical Nutrition, 49(8):605-612. VORSTER, HH; OOSTHUIZEN, W; JERLING, JC; VELDMAN, FJ \& BURGER HM 1997: The nutritional status of South Africans. A review of the literature. Durban: Health Systems Trust. Part 2. 122p.

WACHS, T 1995: Relationship of mild to moderate malnutrition to human development: correlation studies. Journal of Nutrition, 125:2245S-2254S.

WILSON, SH 2000: Medical nutrition therapy for food allergy and food intolerance. (In: Mahan, LK \& EscottStump, S eds. 2000: Krause's Food, nutrition, and diet therapy. Philadelphia: WB Saunders Co. 1194p.)

WRIGHT, CM; CALLUM, J; BERKS, E \& JARVIS, S 1998: Effect of community-based management on failure-to-thrive: randomised controlled trial. British Medical Journal, 317:571-574. 